\title{
Antibiogram analysis and tracking of the virulence-related genes in Enterococcus faecalis isolates
}

\author{
Bagheri Sheshdeh $\mathbf{M}^{1}$, Nazarian-Firouzabadi $\mathrm{F}^{2}$, Ismaili $\mathrm{A}^{3}$, Akrami MJ ${ }^{1}$ \\ 1. MSc Student of Biotechnology, Agronomy and Plant Breeding Department, Faculty of agriculture, Lorestan University, \\ Khorramabad, Iran. \\ 2. Professor of Biotechnology, Agronomy and Plant Breeding Department, Faculty of agriculture, Lorestan University, \\ Khorramabad, Iran (Corresponding Author), Tel: +98-6633400191, E-mail: nazarian.f@lu.ac.ir \\ 3. Associate Professor of Molecular Genetics, Agronomy and Plant Breeding Department, Faculty of agriculture, Lorestan \\ University, Khorramabad, Iran.
}

\begin{abstract}
Background and Aim: Enterococcus species are opportunistic pathogens and their pathogenicity seems to be related to the presence of a number of pathogenicity genes. Since donkey's milk is a new non-allergenic source of nutrition, this study was performed to assess the antibiogram and detection of pathogenicity genes in some Enterococcus faecalis isolates from donkey's milk.

Materials and Method: In this experimental study, several Enterococcus faecalis isolates were isolated from donkey's milk. Resistance patterns of the isolates to 10 antibiotics including vancomycin were investigated based on CLSI protocol. Statistical comparison was made by Fisher's exact test. Polymerase chain reaction (PCR) amplification was used to study gel $\mathrm{E}, e s p$, ace, as and $e f a \mathrm{~A}$ pathogenicity related genes.

Results: Enterococcus faecalis isolates showed a different antibiogram pattern. Isolates were resistant to azithromycin, and erythromycin, but were susceptible to ampicillin and penicillin. Previously isolated LUB93929 and LUB93101 isolates were found to be susceptible and resistance to vancomycin, respectively. GelE, ace and efaA genes were detected in both Enterococcus faecalis isolates and also in Enterococcus faecalis in the control strains. The aggregation substance gene (as) was only amplified in LUB93101 isolate. Interestingly, esp gene was not detected in any of the isolates.

Conclusion: Despite resistance to vancomycin and presence of some pathogenicity related genes in this study, Enterococcus faecalis isolates may not be human pathogens due to lack of pathogenic factors. The esp gene is crucial for biofilm formation and rise of nosocomial infections. Donkey's milk Enterococcus faecalis isolates are not able to form biofilm and seem not to bring any problem.
\end{abstract}

Keywords: Enterococcus faecalis, Antibiogram, Pathogenicity genes, Donkey's milk Received: Jan 6, $2019 \quad$ Accepted: April 29, 2019

How to cite the article: Bagheri Sheshdeh M, Nazarian-Firouzabadi F, Ismaili A, Akrami MJ. Antibiogram analysis and tracking of the virulence-related genes in Enterococcus faecalis isolates. SJKU 2019;24(2):17-29. 


\title{
بررسى آنتى بيوكرام و رديابى ثذهاى مرتبط بيمارىزا در سويههاى انتروكوكوس فكاليس
}

\author{
مهدى باقرى ششده'، فرهاد نظريان فيروز آبادى'، احمد اسماعيلى"، محمد جواد اكرمى' \\ ا. ادانشجوى كارشناس ارشد بيوتكولوزىى، كروه زراعت و اصلاح نباتات، دانشكده كشاوزىى، دانشكاه لرستان، خرمآباد، ايران.

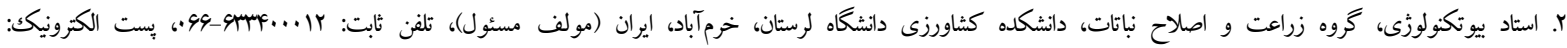 \\ nazarian.f@lu.ac.ir

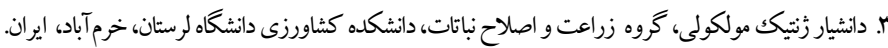

زمينه و هدف: انتروكو كوسها، باتوزنهاى فرصتطلبى هستند كه بيمارىزايى آنها ناشى از حضور جند زن عامل بيمارىزايى

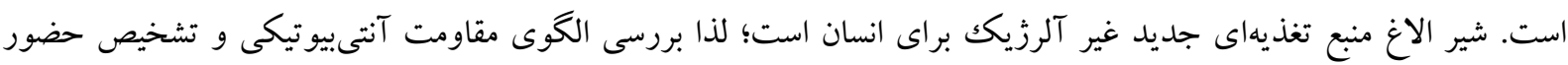
برخى زنهاى مهم و مؤثر در بيمارىزايى انترو كو كوس فكاليس هاى جداسازى شده از آن ضرورت دارد.

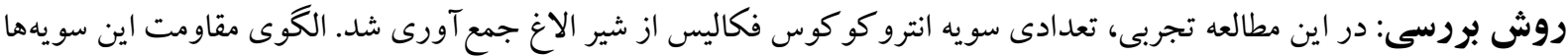
نسبت به ده آنتىبيوتيك از جمله ونكومايسين بر اساس بروتكل CLSI و با استفاده از آزمون فيشر مورد بررسى و مقايسه قرار كرفت. آزمون تكثير زنهاى بيمارىزايى gelE، يافتهها: سويههاى انترو كو كوس فكاليس نسبت به آنتىبيوتيكك هاى اريترومايسين و آزيترومايسين مقاوم و نسبت به آمبى سيلين و

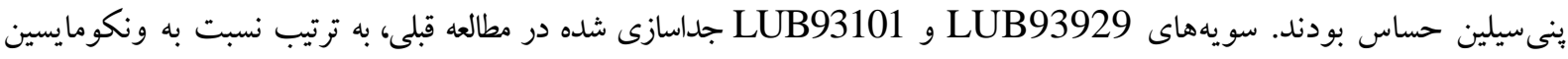

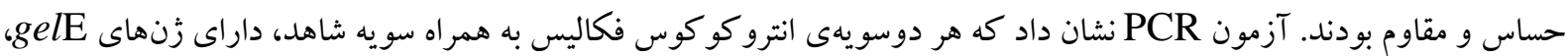
efaA نتيجه كيرى: عليرغم وجود برخى زنهاى بيمارىزا و مقاومت به ونكومايسين در برخى از سويهها، به دليل عدم وجود مجموع

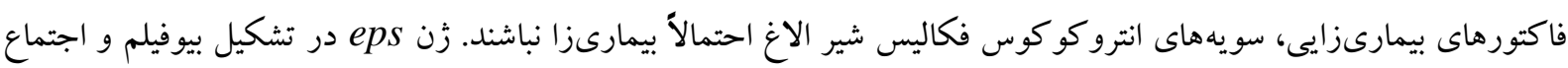

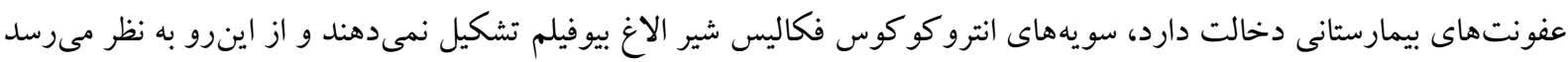
كه مشكل ساز نباشند.

$$
\begin{aligned}
& \text { كليد وازه ها: انتروكو كوس فكاليس، آنتى بيو گرام، زن بيمارىزايى، شير الاغ } \\
& \text { وصول مقاله: 9V/1/19 اصلاحيه نهايى: 9N/T/Y يذيرش:9N/T/9 }
\end{aligned}
$$


كلازن (ace: collagen-binding protein)، آنتىزن efaA: E. faecalis Endocarditis Antigen ) A A و كֶّول پِلى ساكاريدى ديواره سلولى است (4-Y). مشخصات زنهاى بيمارىزايى و زل الكتروفورز در ميدان

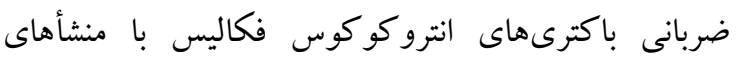

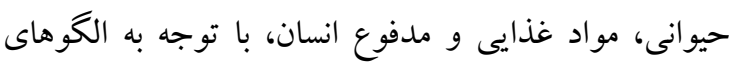

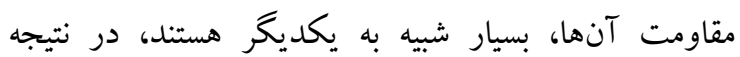

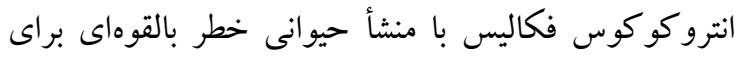
انسان از نظر ريسك إيدمى در جوامع انسانى محسوب

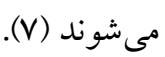

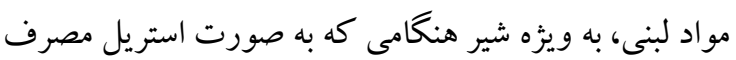

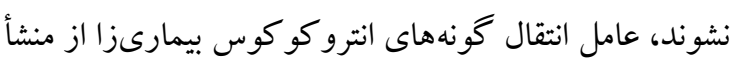

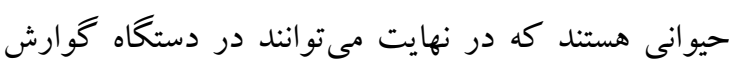

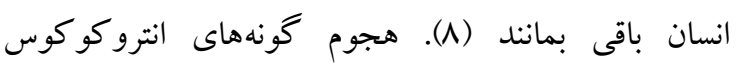

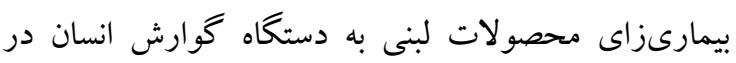

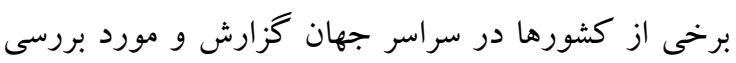

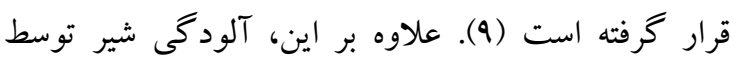

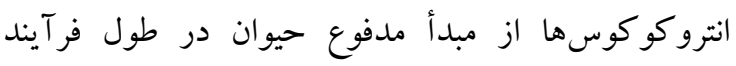

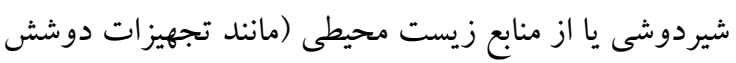

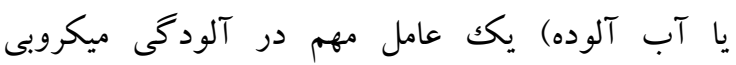

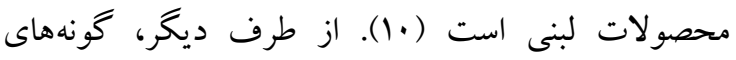

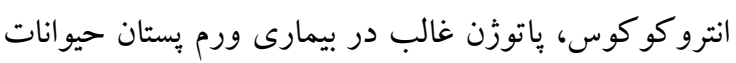

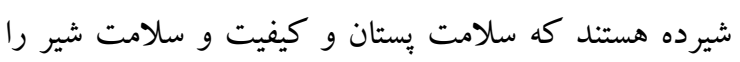

تحت تأثير قرار مىدهند (11).

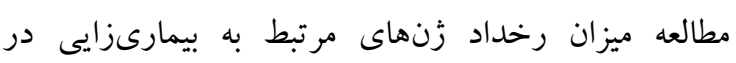

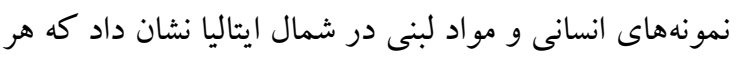
دو كونه Enterococcus faecalis Enterococcus faecium داراى زنهاى بيمارىزاى

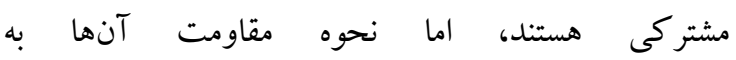
آنتىبيوتيككهايرايج متفاوت است (Y) (Y). در مطالعه ديخرى

\section{مقدمه}

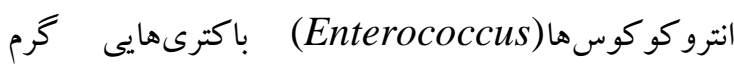
مثبت و كاتالاز منفى هستند كه به طور طبيعى در دستكاه

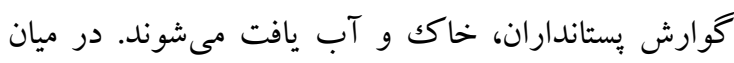

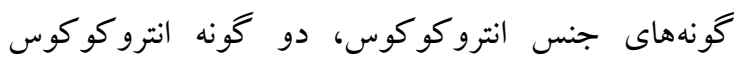

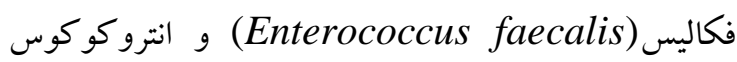

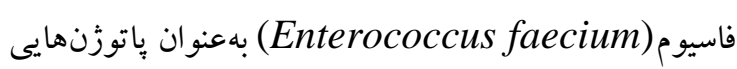

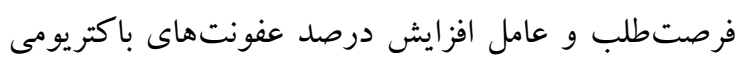
داخل شكمى و عفونتهاى دستگاه ادرارى شناخته شده

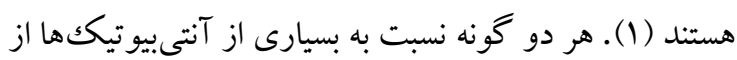

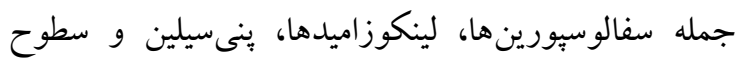

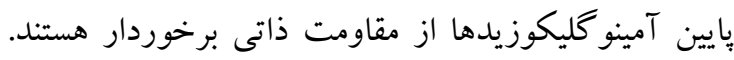

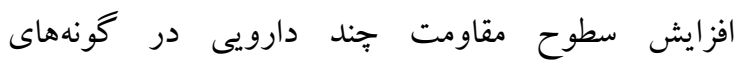
انتروكو كوس فكاليس و انتروكو كوس فاسيوم به صورت

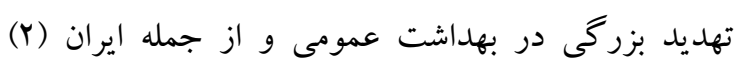

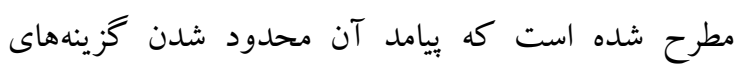
درمانى است. هنگامى كه مقاومت به آميى سيلين وجود داشته

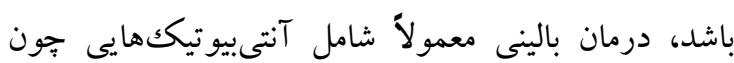

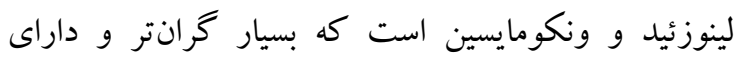

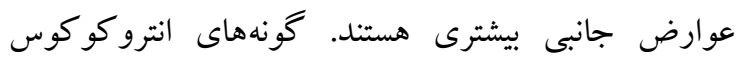

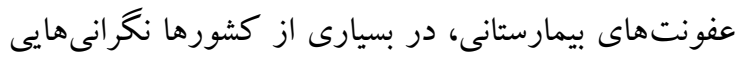

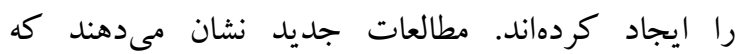

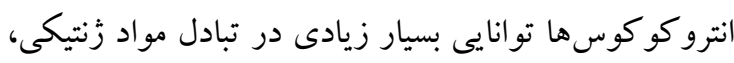

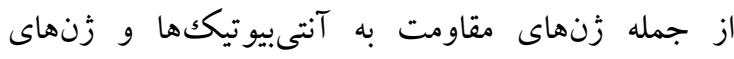

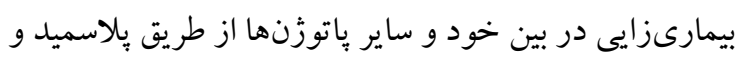

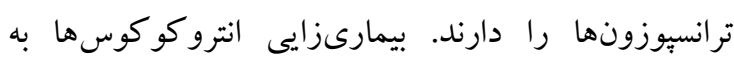
خصوص انتروكو كوس فكاليس، تحت كنترل زنهاى

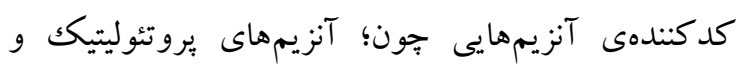

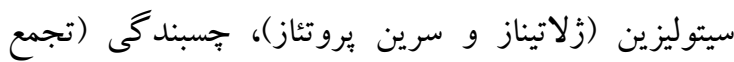

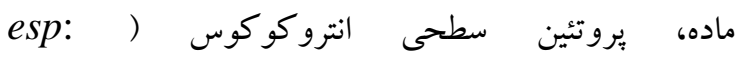
enterococcal surface protein 
نخرفته است. اين مطالعه با هدف بررسى ارتباط زنهاى

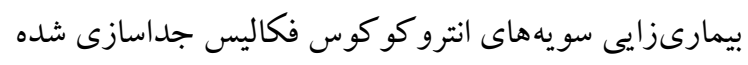

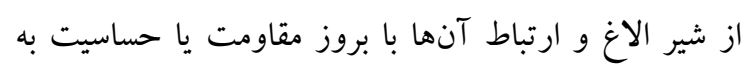

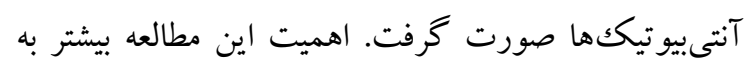
اين خاطر است كه اطلاع از سويههايى ميكروبى موجود در

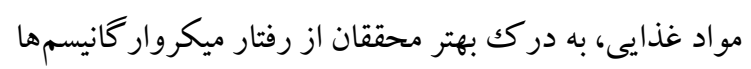
فرصتطلب در ايجاد اييدمى و مخاطرات آتى به وسيله آنها كمكك مى كند.

\section{مواد و روشها} شناسايی باكترىهاى انتروكو وكوس Akrami لاكتيك را بر اساس مطالعات استاندارد ميكروبيولوزيكى همارن

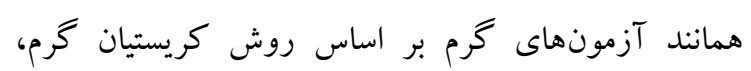
كاتالاز، توانايى رشد در دماهاى C Cr

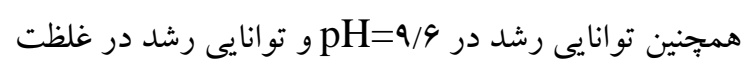
9/D (W/V)

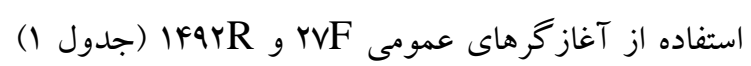
ناحيه 19S rRNA دوسويهى انتخابى به شكل تصادفى

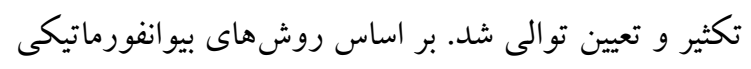

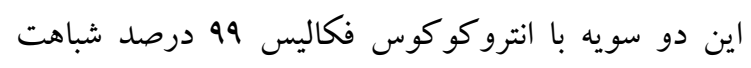

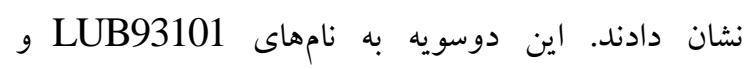

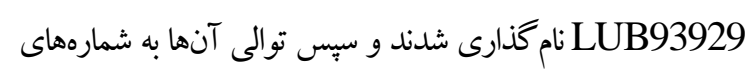
دسترسى بانكك زن KP298396 و

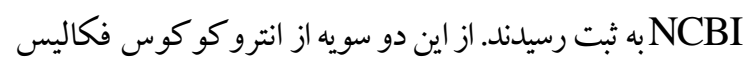

براى ادامهى بقيهى مطالعات در اين تحقيق استفاده شد.

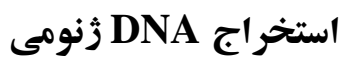

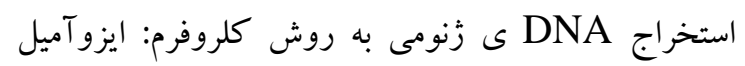

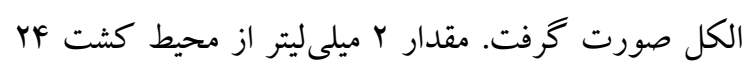

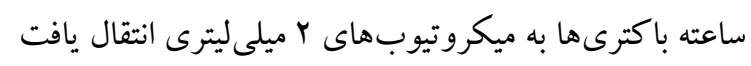
و در rpm ...... به مدت ه دقيقه سانتريفيوز شد. مايع روشناور دور ريخته شد و رسوب باكترىها س مرتبه به منظور
كه در برزيل روى سلامت شير بوفالو صورت گرفت،

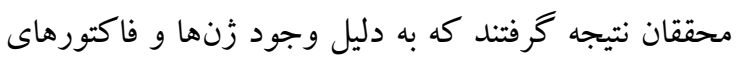

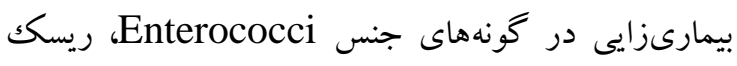

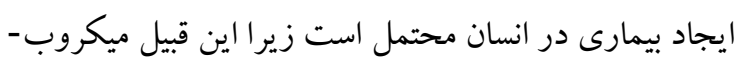

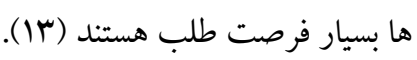
عليرغم مزاياى فراوان شير الاغ همانند جربى كم، همب، كازئين پايين، ليزوزيم فراوان، وجود مقادير بالايى از اسيدهاى

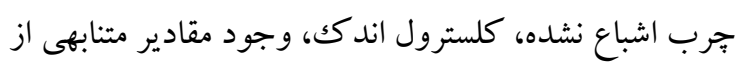

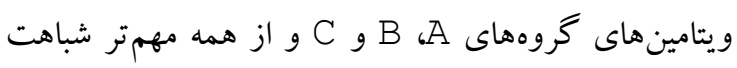
كمنظير آن به شير انسان، هنوز تحقيق جامعى در خصوص فلور باكتريايى آن صورت نغرفته است. مطالعات در مورد تركيبات غذايى و ارزش تغذيهاى شير الاغ سابقهاى طولانى

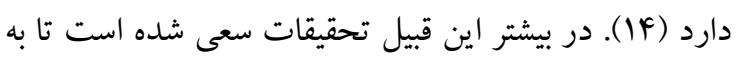

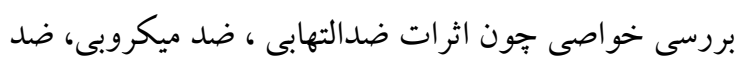

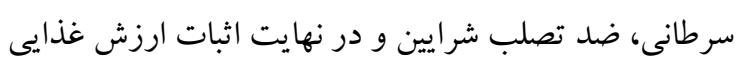

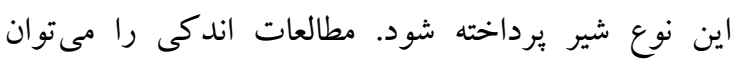
برشمرد كه روى جنبهاى بهداشتى و شناسايى عوامل

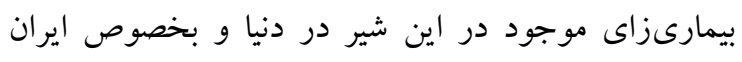

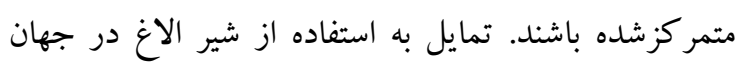
به عنوان يكك منبع غذايى جانشين نسبت به شير گاو در حال افزايش است. در ايران عشاير با توجه به نوع معيشت آنها

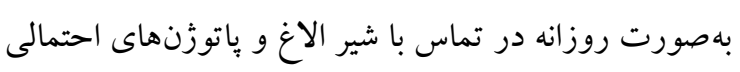

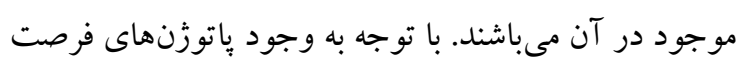

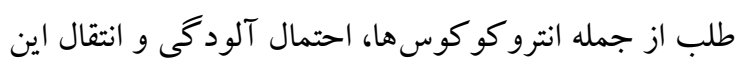

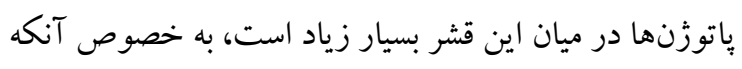
امروزه بسيارى از مردم به مصرف لبنيات محلى روى آوردهـ

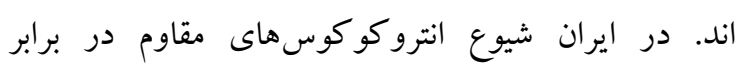

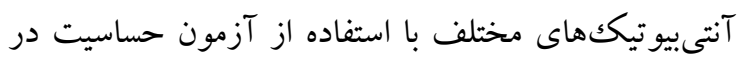

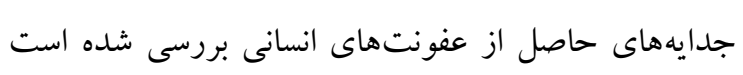
(Y ، 1D-IV)

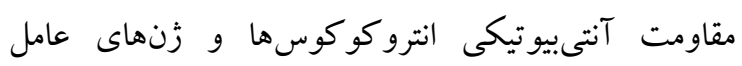

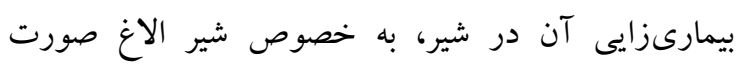


دستور العمل شركت يادتن طب (www.padtanteb.ir)

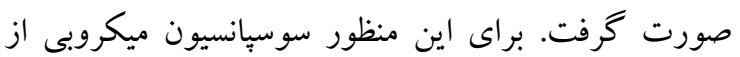

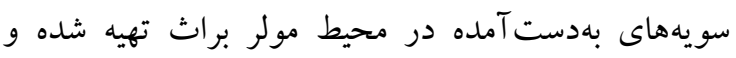

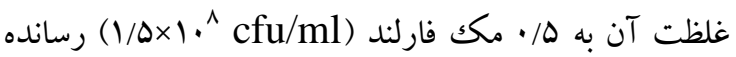
شد. با استفاده از سواب استريل روى محيط مولر هينتون آكار كشت متراكم صورت گرفت و برخى از متداولترين

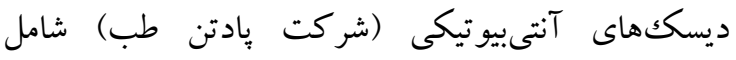

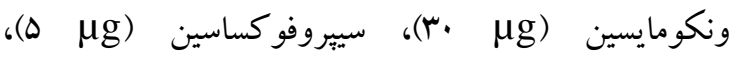
نيتروفورانتوئين ( آزيترومايسين (

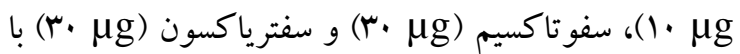
فاصله مناسب حداقل Y/ه سانتىمترى بر اساس روش انتشار

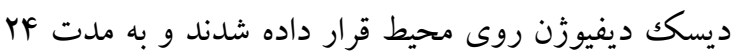
ساعت گرما گذارى صورت گرفت (نمودار (1). قطر هالههاى عدم رشد اطراف ديسككها بعد از خارج كردن از انكوباتور بر اساس دستورالعمل شركت سازندهى ديسكها اندازهيرى شد. لازم به ذكر است كه در آزمون تعيين حساسيت و شناسايى زنهاى عامل بيمارىزايى، از باكترى ( Enterococcus faecalis (ATCC 29212 شاهد (مركز كلكسيون ميكروار كانيسم هاى صنعتى، سازمان يزروهش هاى علمى و صنعتى ايران) استفاده شد. شناسايى زنهاى عامل بيمارىزايى زنهاى عامل بيمارىزايى زلاتيناز (gelE)، يروتئين سطحى

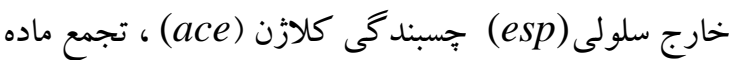
) و آنتىزن اندو كارديت انتروكو كوس فكاليس (as) (efaA با استفاده از آغازگرهاى اختصاصى آنها (جدول (1) توسط PCR تكثير شدند.
حل نمودن DNA در فاز مايع، با بافر تريس-ادتا-كلريد TEN (EDTA100mM, NaCl 150mM, سديم و هر بار در Tris HCl 100mM) دقيقه شتشو داده شد. به رسوبهاى حاصل، بافرى متشكل

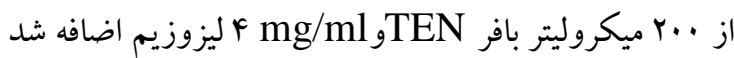
تا ارتباطات بين يبتيدو گليكانها در ديواره باكترىها شكسته شود و به دنبال آن انكوباسيون به مدت ها دقيقه در دماى

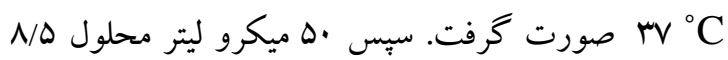

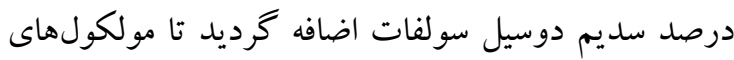

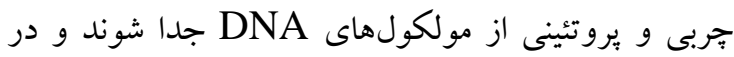

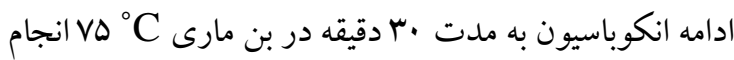

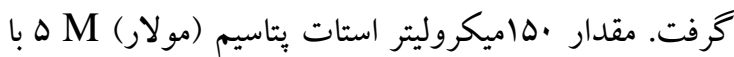
روى يخ به نمونهها اضافه شد تا كمبلكس سديم دوسيل سولفات -بروتئينها و جربىها به كمكك ايزواميل

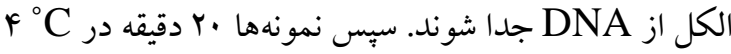
نخهدارى شدند. سِّ سانتريفيوز به مدت هـ دقيقه در

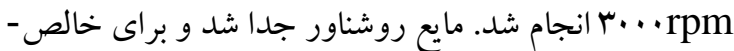
سازى DNA از يروتئينها، از مخلوط فنل: كلروفرم: ايزواميل الكل (1:Y:Y:Y ) استفاده شد. به منظور رسوبدهيى DNA از ايزويرويانول سرد استفاده شد. در آخر، براى شستشوى DNA، از اتانول •V درصد استفاده شد. رسوبهاى DNA در دماى آزمايشكاه خشك شدند و رسوب حاصل در •ها ميكروليتر آب دو بار تقطير استريل حل شدند. غلظت DNA توسط روش اسبكتروفتومترى و

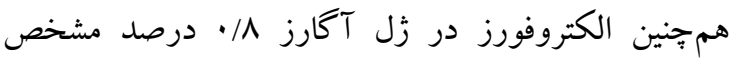

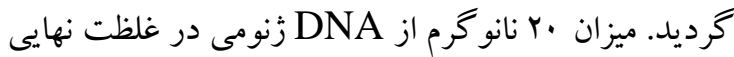
در واكنش PCR استفاده شد.

\section{آزمون تعيين حساسيت (آنتى بيو كرام)}

حساسيت سويهها با روش انتشار در ديسك دئ (Disk)

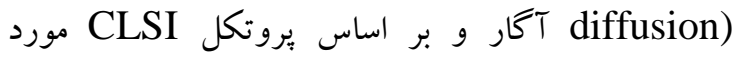

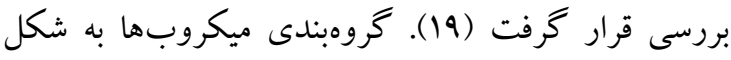
حساس، نيمه حساس و مقاوم بر اساس جداول ارائهشده در 
جدول ا: آغاز گرهاى PCR و شر ايط واكنش. تمامى برنامهاى PCR شامل: ·r جرخه واسرشتخى در دماى

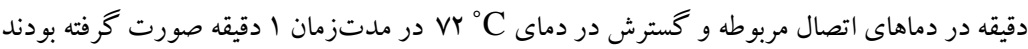

\begin{tabular}{|c|c|c|c|c|}
\hline زن & 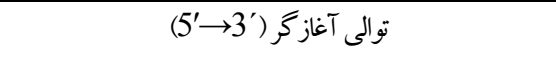 & طول محصول PCR & دماى اتصال & منبع \\
\hline $\mathrm{ACEF}$ & AAAGTAGAATTAGATCCACAC & m. & $\Delta 9$ & 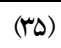 \\
\hline ACE R & TCTATCACATTCGGTTGCG & & & \\
\hline gelEF & AGTTCATGTCTATTTTCTTCAC & F.r & $\Delta 9$ & (14) \\
\hline gelE R & CTTCATTATTTACACGTTTG & & & \\
\hline efaA F & CGTGAGAAAGAAATGGAGGA & 199 & $\Delta 9$ & 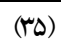 \\
\hline efaA R & CTACTAACACGTCACGAATG & & & \\
\hline AS F & CCAGTAATCAGTCCAGAAACAACC & 4.9 & $\Delta f$ & (ra) \\
\hline AS R & TAGCTTTTTTCATTCTTGTGTTTGTT & & & \\
\hline esp46F & TTACCAAGATGGTTCTGTAGGCAC & Try & $\Delta \wedge$ & 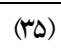 \\
\hline esp47 R & CCAAGTATACTTAGCATCTTTTGG & & & \\
\hline
\end{tabular}

در دماى اتاق و سبس به مدت يك شب در دماى

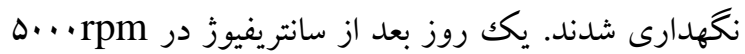

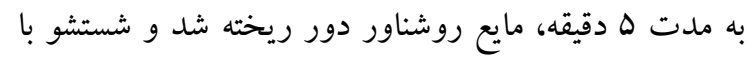

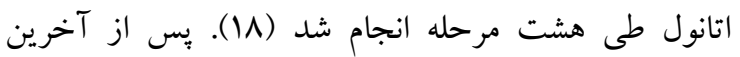
مرحلهى شستشو، رسوب باكترى به مدت ب-r ساعت در دماى rV

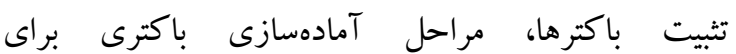
ميكروسكوٍ الكترونى انجام شد. براى اين كار از دستخاه (Denton Desk sputter coater-DSR1 با يوشش نانو ساختار طلا Vacuum LLC, USA)

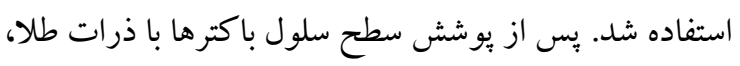
از ميكروسكوب الكترونى (مدل FE SEM / Mira3

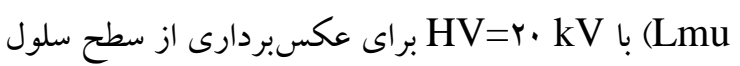

$$
\text { باكترى استفاده شد. }
$$

فراوانى رخداد زنهاى بيمارىزايى در بين دوسويه ميكروبى Enterococcus faecalis

\section{شناسايى مورفولوزيكى باكترىها با استفاده از

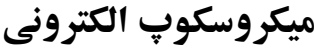

به منظور اطمينان از شناسايى بيوشيميايى و مولكولى الكيى سويه -

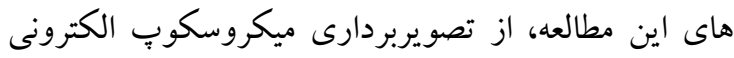

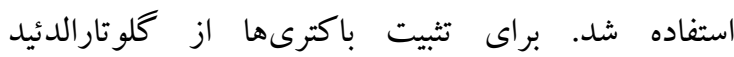
بر اساس روش كلورت و ريد (Glutaraldehyde))

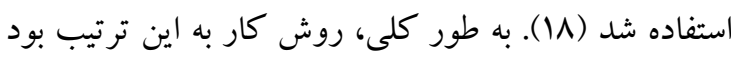
كه ابتدا كشت يكك شبه از باكترى تهيه شد. پِّ از سانتريفيوز باكترها در ب... rpm به مدت لم لا دقيقه، مايع روشناور دور ريخته شد و رسوب باكترىها نخهدارى شد.

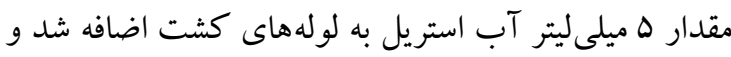
رسوب باكترىها ڤֶ از حل شدن با دور f...rpm شستشو داده شدند. شستشو دو بار ديخر تكرار شد تا بقاياى

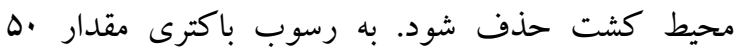
ميكروليتر از محلول كلوتار آلدهيد و بافر فسفات اضافه شد و

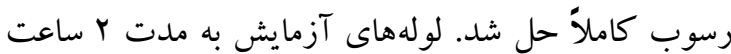


دوسويه اختلاف معنى دارى ( ( • > P ) با هم نداشتند. از

ميان دوسويهى مورد آزمايش سويهى LUB93101 به ونكومايسين مقاوم و سويه LUB93929 همانند شاهد به ونكومايسين حساس بودند (شكل (). دو سويه از نظر سطح مقاومت يا حساسيت نسبت به ساير آنتى بيو تيكها تفاوتهايى را نشان دادند. در آزمون شناسايى زنهاى عامل بيمارىزايى، هر دوسويهى انترو كو كوس فكاليس جداسازى شده از شير و گونه شاهد، همخى داراى زنهاى efaA ace ،gelE بودند. تنها در سويه LUB93929 زن as تكثير شد و زن esp در هيجيكك از نمونهها يافت نشد (شكل Y).
استفاده از نرمافزار SAS ver 9.1 براى هر كدام از زنها در سطح احتمال ه • > > Pورد مقايسه قرار گرفت. نتايج نتايج حاصل از آزمون تعيين حساسيت سويههاى انتروكوكوس فكاليس جداسازى شده از شير الاغ نشان داد كه هر دو سويه به طيفى از آنتىبيوتيكها مقاوم هستند. همانطورى كه ديده مىشود، هر دوسويهى اين مطالعه

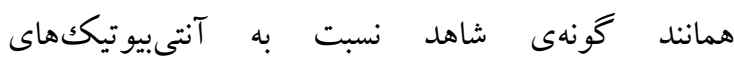
اريترومايسين، آزيترومايسين و سفترياكسون مقاوم هستند. بيشترين ميزان حساسيت مربوط به آنتىبيوتيكهاى بتا لاكتام (ينىسيلين و آميىسيلين) بود كه در اين مورد

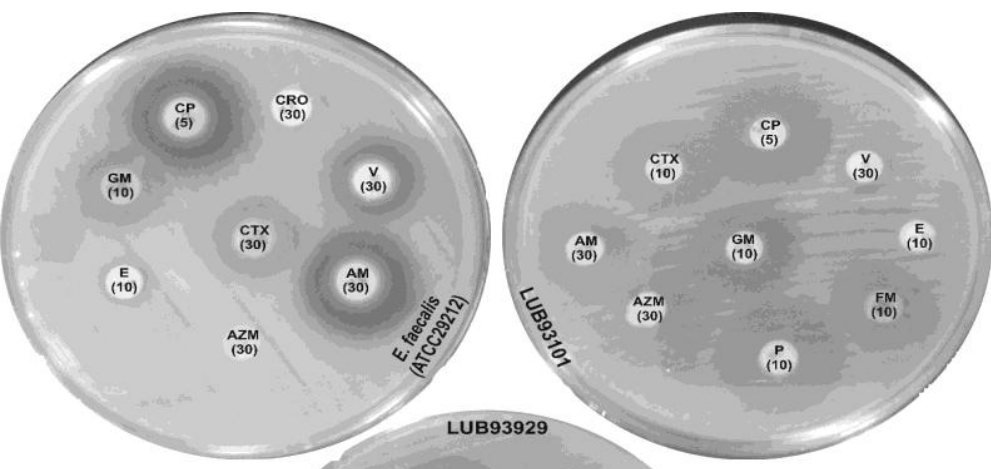

AM

CRO
$(30)$

AZM

(10)

(30)

(10)

AM)

شكل ا: نتايج حاصل از آزمون تعيين حساسيت باكترىهاى انتروكو كوس فكاليس حاصل از شير الاغ. آميىسيلين (AM)، (AM)، نيتروفورانتوئين

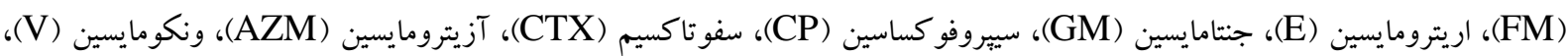
بنى سيلين (P)، سفترياكسون (CRO). از دستورالعمل شر كت سازندهى ديسككها براى تعيين مقاومت، مقاومت يا حساسيت حد واسط و

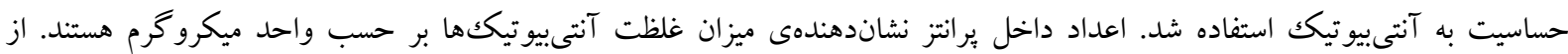
باكترى( Enterococcus faecalis ATCC29212) بهعنوان شاهد استفاده شد 


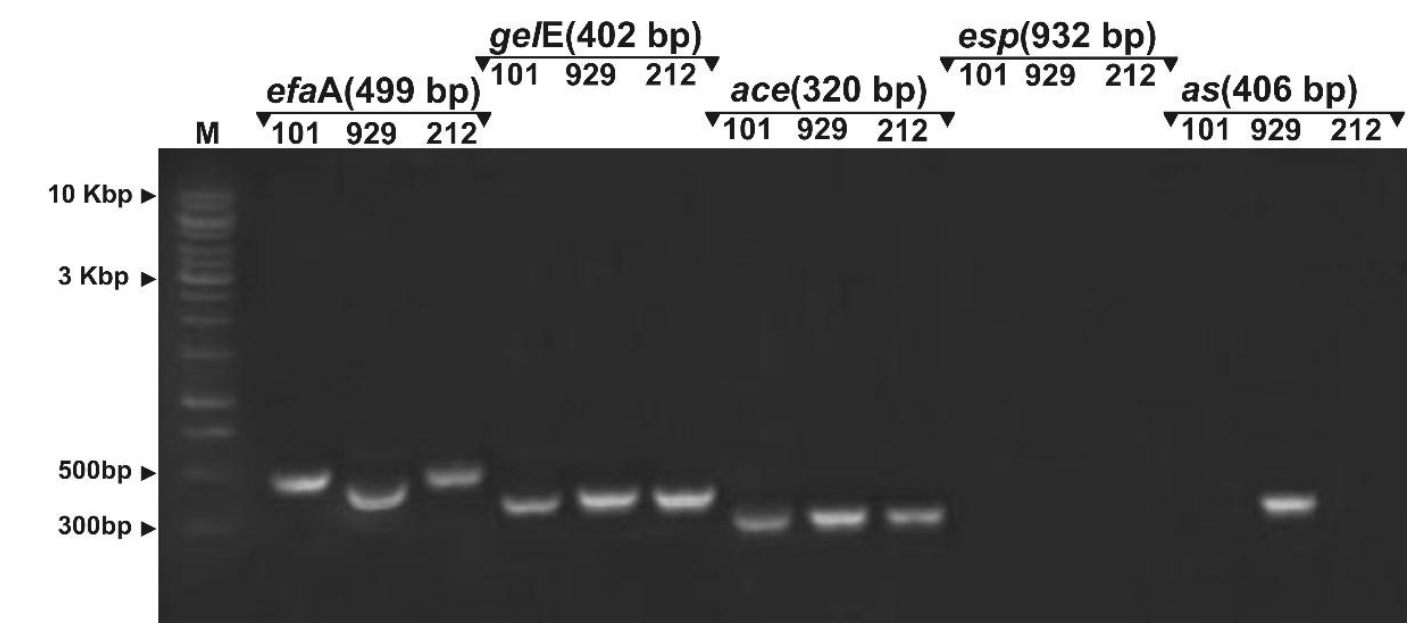

شكل r: تشخيص زنهاى عامل بيمارىزايى در سويههاى انتروكو كوس فكاليس جداسازى شده از شير الاغ سويههاى

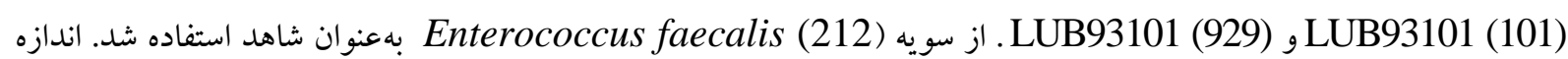

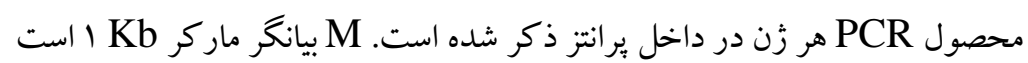

باكترىهاى استريتو كو كوس، شباهت زيادى مشاهده مى -

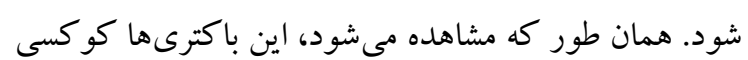
شكل و دوتايى هستند.
نتايج حاصل از تصويربردارى با ميكروسكوب الكترونى از

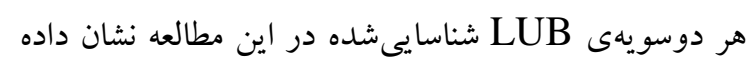

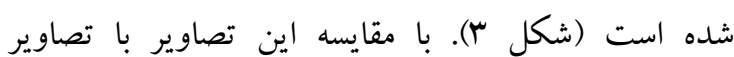

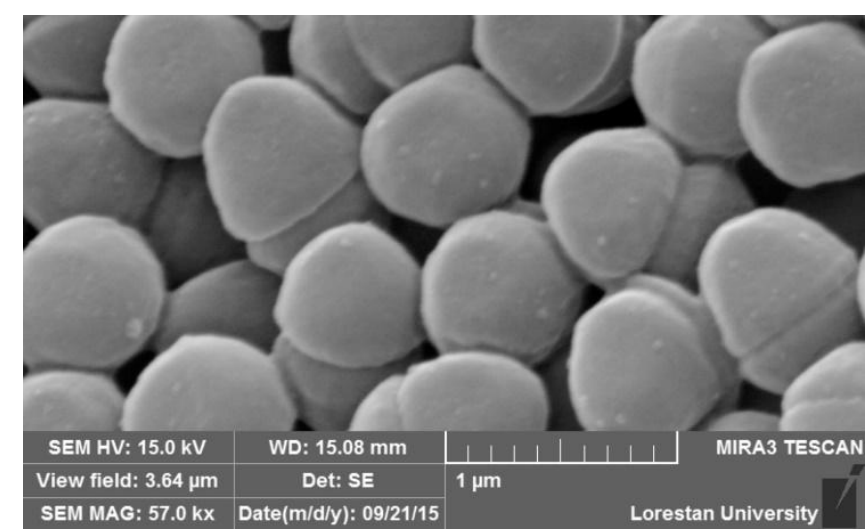

شكل rّ: تصوير باكترىهاى انترو كو كوس فكاليس سويهها LUB93101 با استفاده از ميكروسكوٍ الكترونى

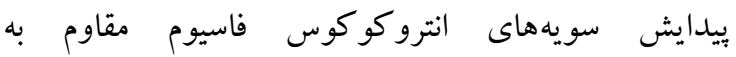
ونكومايسين در ارويا و انتروكو كوس فكاليس دور دروسئ امريكا، از انتروكو كوسها بهعنوان سومين عامل عفونت مجارى هشدارى جدى در خصوص بروز سويههاى انتروكو كوس

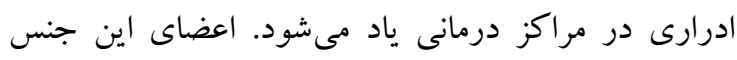

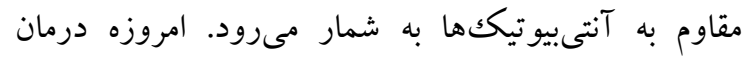

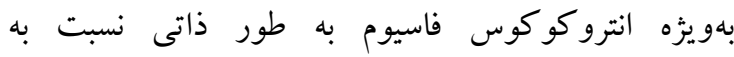
عفونت ناشى از جنين انتروكو كوسهايى نياز به توجه و بهو

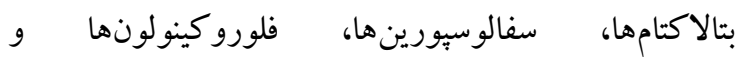

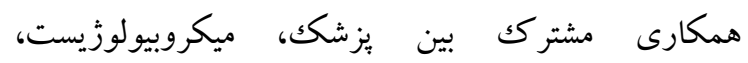

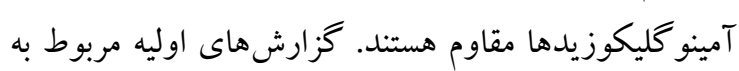




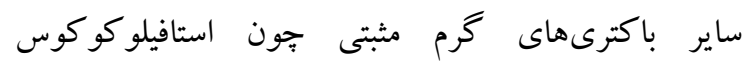
اورئوس (Staphylococcus aureus)، استريتو كو كوس خرم ينومونيه (Streptococcus pneumoniae) و و ياتوني استريتو كو كوس بيوزنز (Streptococcus pyogenes) جز عوامل بيمارىزاى بدخيم نيستند، مطالعه بيمارىزايى

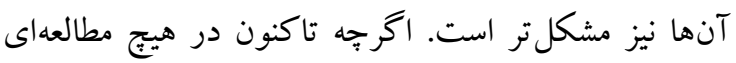

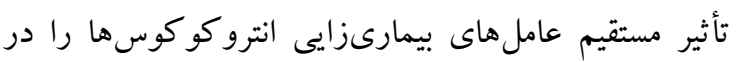
عفونتهاى انسانى مشخص نكردهاند، اما تعدادى از اين

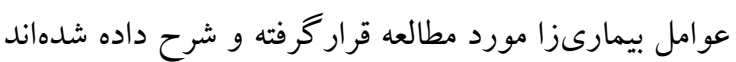
(YY) انسولين، كازئين، همو كلوبين، كلازن، زلاتين و فيبرين است

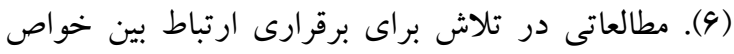

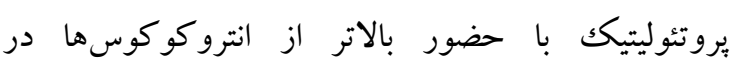

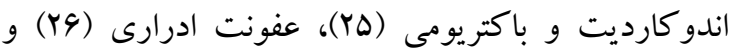
عفونتهاى دهان (YV) انجام شده است. با اين حال،

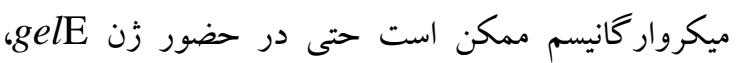

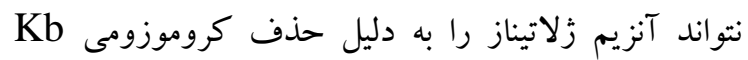

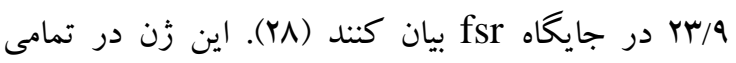

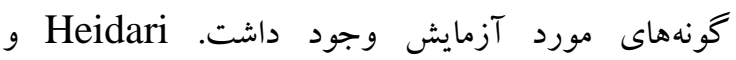

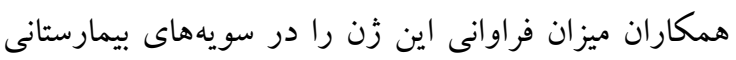
انتروكو كوس فكاليس جداسازى شده از بيماران بيمارستان

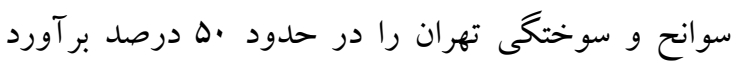
كردند (Yq). يروتئين سطحى انترو كو كوس توسط زن تهرد

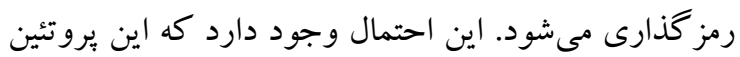
در استقرار و دوام انتروكو كوس فكاليس در طول عنو عفونت

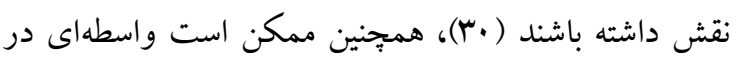
واكنش اوليه ياتوزن با سطوح ميزبان در طول تشكيل بيوفيلم

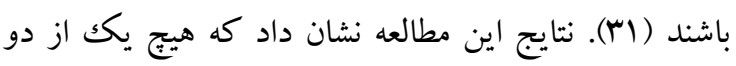
سويهى جداسازى شده از شير الاغ همانند سويهى شاهد Enterococcus faecalis ATCC29212 esp نبودند (نمودار Y). اين موضوع يافتهى جالب توجهى

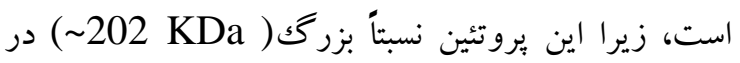

بيوتكنولوزيست و ساير تخصصهاى كادر مراقبت بهداشتى

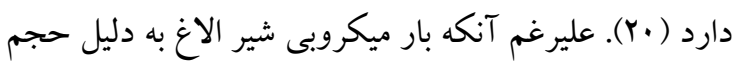

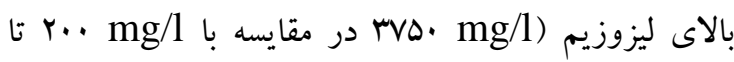

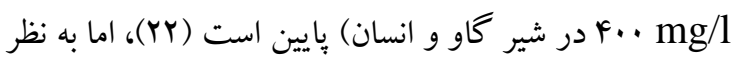

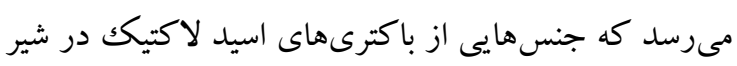

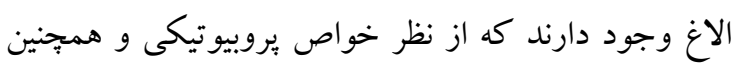

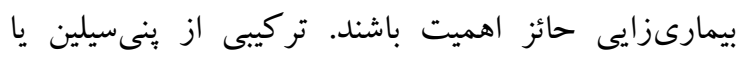

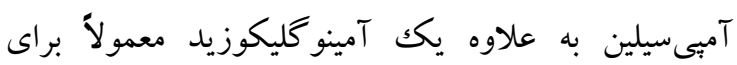
عفونتهاى جدى با منشأ انتروكوكى، مانند اندوكارديت تجويز مىشود. خوشبختانه نتايج حساسيت جدايه هاى مورد آنساي

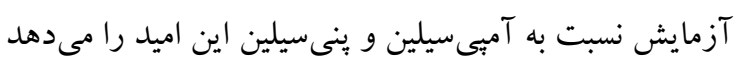

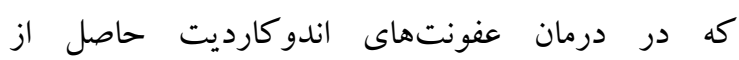
انترو كو ككها مىتوان از اين آنتىبيوتيككها استفاده نمود.

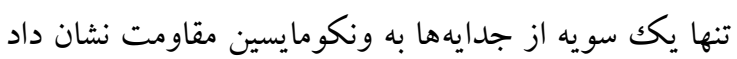
و ساير سويهها همگیى حساس بودند. از آنجايى كه انتروكو كوسها پِاتوزنهايى فرصت طلب هستند، احتمال انتقال عامل مقاومت به ونكومايسين به ساير سويهها نيز

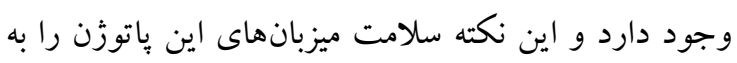

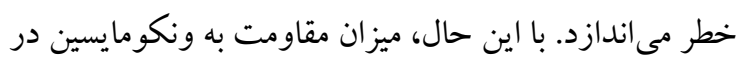

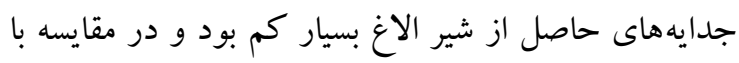
اطلاعات مربوط به سويههاى بيمارستانى و ساير سويههاى

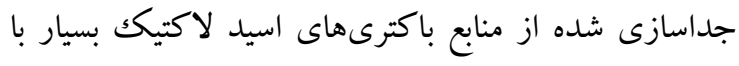

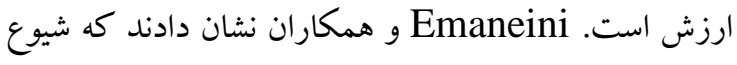

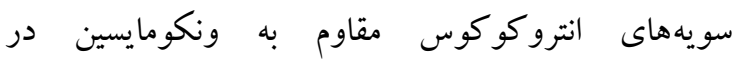

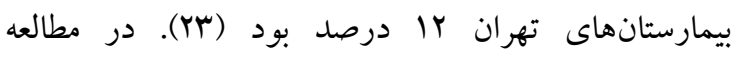
Saderi

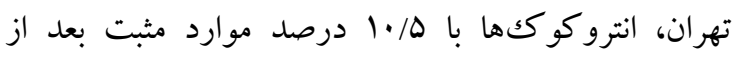
اشرشياكولى در مقام دوم قرار داشتند (19). در مطالعه ديخرى كه توسط Amin و همكاران در بيمارستان امام

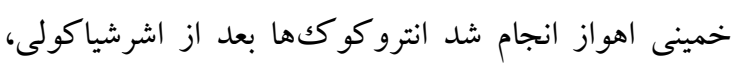

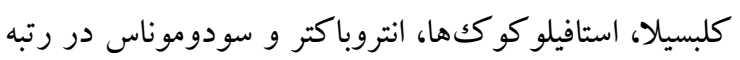
ششم قرار داشتند (IV). از آنجايى كه انتروكو كوس ها مانند 
با مطالعه قبلى و همجينين يافتهاى اين تحقيق را نشان مى- دهى

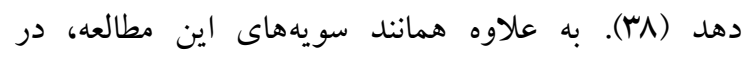

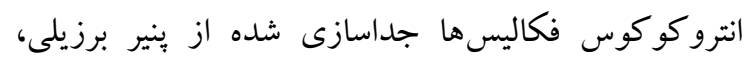

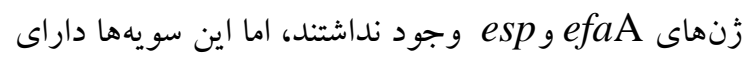

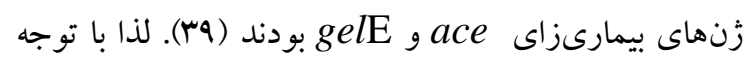
به وجود برخى فاكتورهاى بيمارىزايى در باكترىهاى شير

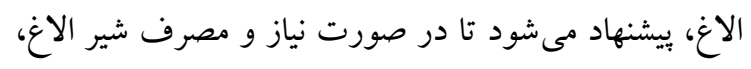

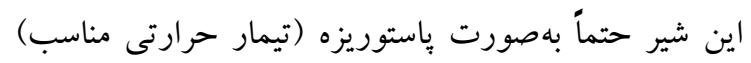

$$
\text { مصرف شود. }
$$

\section{نتيجه كيرى}

نتايج اين مطالعه نشان داد كه با وجود حضور برخى از زن -ن

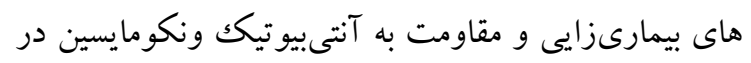

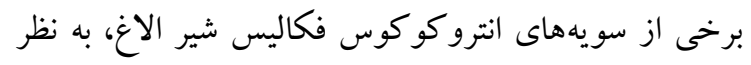

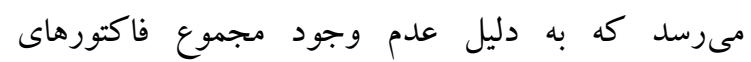

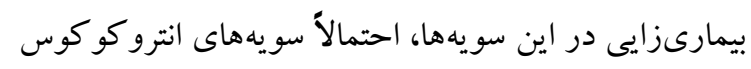

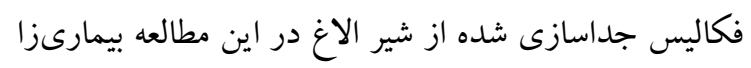

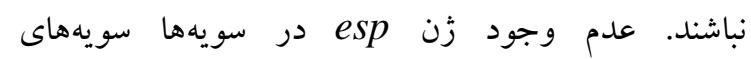
انتروكو كوس اين مطالعه كه در تشكيل بيوفيلم و اجتماع

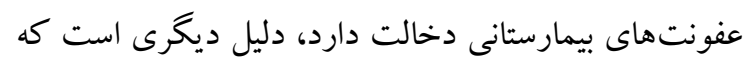
سو يهاى انترو كو كوس فكاليس شير الاغ اين مطالعه احتمالاً

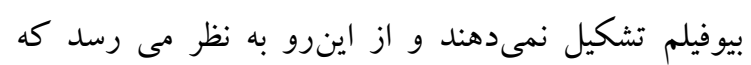
بيمارىزا نبوده و از نظر بالينى مشكل ساز نباشند.

\section{تشكر و قدردانى}

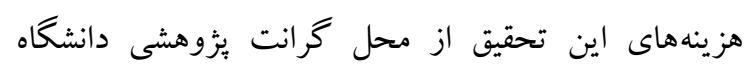

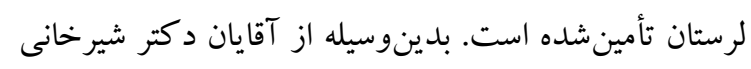

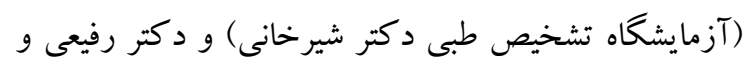

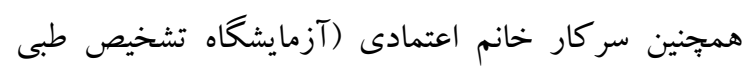

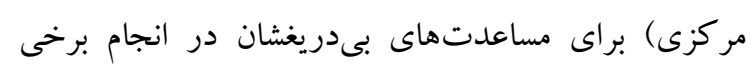
آزمايشهاى ميكروبى قدردانى مى مرود.
تشكيل لايه بيوفيلم روى ادوات جراحى دخالت دارد (rr)

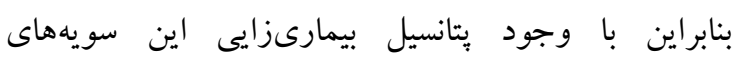

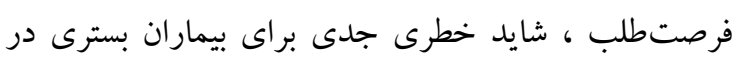

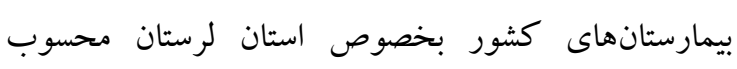

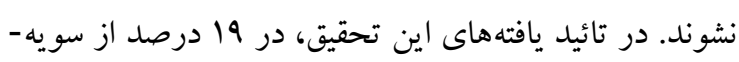
هاى انترو كو كوس بيمارستانى زن esp مشاهده شد كه نشان

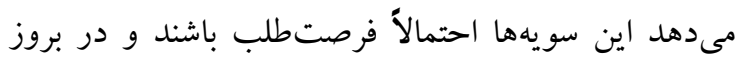

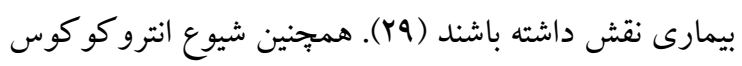

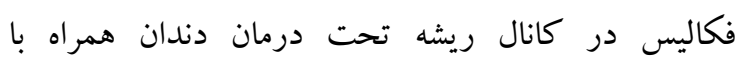
بريودنتيت آيكال(Apical Periodontitis) بسيار

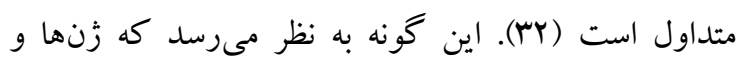

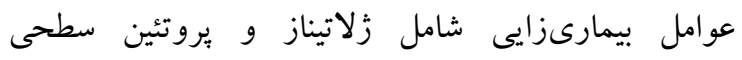

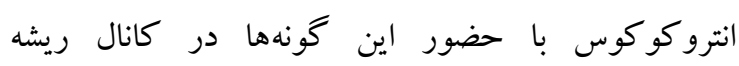

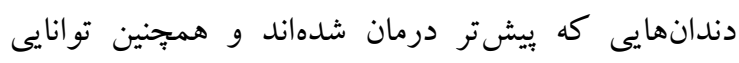

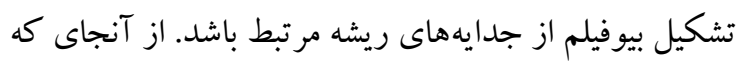

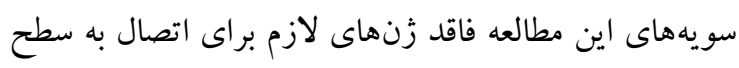

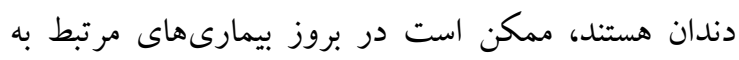
كانال ريشه نقش نداشته باشند. تا آنجا كه اطلاعات ما نشان مىدهد، اين تحقيق براى اولين باتيند

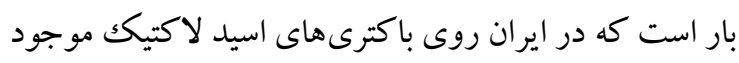
در شير الاغ بهعنوان منبع جديدى از اين باكترىها متمركز

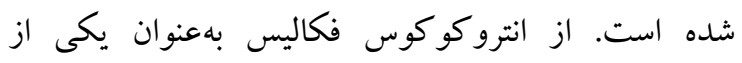
باكترىهاى اسيد لاكتيك فرصت طلب در مقاوم شدن به آنرو

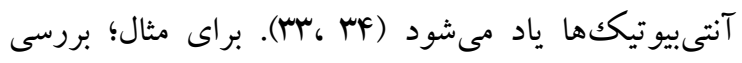

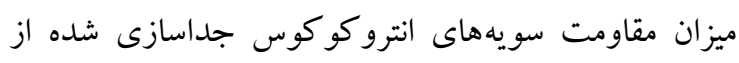

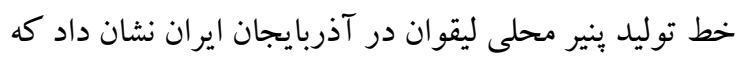

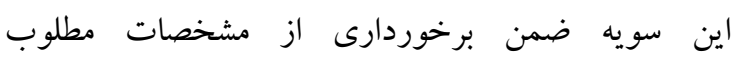

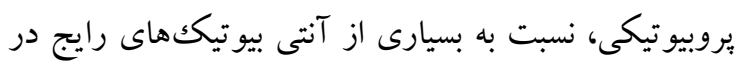

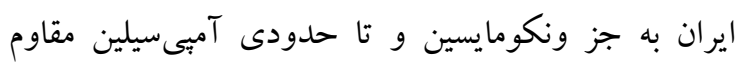

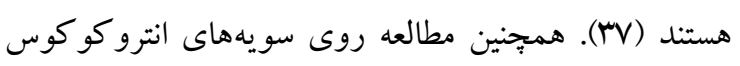
جداسازى شده از بنيرهاى محلى جنوب ايتاليا نيز نتايج مشابه 


\section{References}

1. Conde-Estévez D, Grau S, Albanell J, Terradas R, Salvadó M, Knobel H. Clinical characteristics and outcomes of patients with vancomycin-susceptible Enterococcus faecalis and Enterococcus faecium bacteraemia in cancer patients. Eur J Clin Microbiol Infect Dis 2011;30:103-8.

2. Hoseinizadeh A, Abtahi H, Shoja Pour M, Akbari M, Nazari R, Sofian M. Prevalence and antimicrobial susceptibility pattern of vancomycin resistant enterococci isolated from clinical sample of educational hospitals in Arak. J Arak Uni Med Sci 2012;15:11-6 . [In Persian]

3. Sava I, Heikens E, Huebner J. Pathogenesis and immunity in enterococcal infections. Clin Microbiol Infect 2010;16:533-40.

4. Kayaoglu G, Ørstavik D. Virulence factors of Enterococcus faecalis: relationship to endodontic disease. Crit Rev Oral Biol Med 2004;15:308-20.

5. Medeiros AW, Pereira RI, Oliveira DV, Martins PD, d'Azevedo PA, Van der Sand S, et al. Molecular detection of virulence factors among food and clinical Enterococcus faecalis strains in South Brazil. Braz J Microbiol 2014;45:327-32.

6. Waters C, Antiporta M, Murray B, Dunny G. Role of the Enterococcus faecalis gelE protease in determination of cellular chain length, supernatant pheromone levels, and degradation of fibrin and misfolded surface proteins. J Bacteriol 2003;185:3613-23.

7. Larsen J, Schønheyder H, Singh K, Lester C, Olsen S, Porsbo L, et al. Porcine and human community reservoirs of Enterococcus faecalis, Denmark. Emerg Infect Dis 2011;17:239597.

8. Novais C, Coque T, Costa M, Sousa J, Baquero F, Peixe L. High occurrence and persistence of antibiotic-resistant enterococci in poultry food samples in Portugal. $\mathrm{J}$ Antimicrob Chemother 2005;56:1139-43.

9. Jamet E, Akary E, Poisson M, Chamba J, Bertrand X, Serror P. Prevalence and characterization of antibiotic resistant Enterococcus faecalis in French cheeses. Food Microbiol 2012;31:191-8.

10. Poznanski E, Cavazza A, Cappa F, Cocconcelli P. Indigenous raw milk microbiota influences the bacterial development in traditional cheese from an alpine natural park. Int $\mathbf{J}$ Food Microbiol 2004;92:141-51.

11. Rysanek D, Zouharova M, Babak V. Monitoring major mastitis pathogens at the population level based on examination of bulk tank milk samples. J Dairy Res 2009;76:11723.

12. Cariolato D, Andrighetto C, Lombardi A. Occurrence of virulence factors and antibiotic resistances in Enterococcus faecalis and Enterococcus faecium collected from dairy and human samples in North Italy. Food Control 2008;19:886-92.

13. Pereira RI, Prichula J, Santestevan NA, D'Azevedo PA, Motta AdSd, Frazzon APG. Virulence profiles in Enterococcus spp. isolated from raw buffalo's milk in south Brazil. Res $\mathbf{J}$ Microbiol Dubai 2017;12:248-54.

14. Guo H, Pang K, Zhang X, Zhao L, Chen S, Dong M, et al. Composition, physiochemical properties, nitrogen fraction distribution, and amino acid profile of donkey milk. J Dairy Sci 2007;90:1635-43.

15. Feizabadi M, Asadi S, Zohari M, Gharavi S, Etemadi G. Genetic characterization of highlevel gentamicin-resistant strains of Enterococcus faecalis in Iran. Canadian $\mathbf{J}$ Microbiol 2004;50:869-72. 
16. Saderi H, Owlia P, Jalali Nadoushan M, Zaeri F, Zandieh E. A 3-year study of demographic characteristics of patients with urinary tract infection, microbial etiology, and susceptibility of isolated bacteria to antibiotics in shaheed mostafa khomeini hospital. Iranian J Pathol 2006;1:99-104.

17. Amin M, Manijeh M, Zohreh P. Study of bacteria isolated from urinary tract infections and determination of their susceptibility to antibiotics. Jundishapur $\mathrm{J}$ Microbiol 2009;2009:118-23.

18. Akrami MJ, Nazarian-Firouzabadi F, Ismaili A, Bagheri sheshdeh M. Isolation and identification of probiotic lactic acid bacteria from donkey milk. Yafteh 2015;17:99-108. [In Persian]

19. Bonev B, Hooper J, Parisot J. Principles of assessing bacterial susceptibility to antibiotics using the agar diffusion method. J Antimicrob Chemother 2008;61:1295-301.

20. Glauert AM, Reid N. Fixation, dehydration and embedding of biological sp ecimens: North-Holland Pub. Co. Sole distributors for the USA and Canada. American Elsevier Pub Co; 1974.

21. Murray B. Diversity among multidrug-resistant enterococci. Emerg Infect Dis 1998;4:3747.

22. Carminati D, Tidona F, Fornasari M, Rossetti L, Meucci A, Giraffa G. Biotyping of cultivable lactic acid bacteria isolated from donkey milk. Letters Appl Microbiol 2014;59:299-305.

23. Emaneini M, Aligholi M, Aminshahi M. Characterization of glycopeptides, aminoglycosides and macrolide resistance among Enterococcus faecalis and Enterococcus faecium isolates from hospitals in Tehran. Pol J Microbiol 2008;57:173-8.

24. Jett B, Huycke M, Gilmore M. Virulence of enterococci. Clin Microbiol Rev 1994;7:46278.

25. Baldassarri L, Creti R, Arciola C, Montanaro L, Venditti M, Di Rosa R. Analysis of virulence factors in cases of enterococcal endocarditis. Clin Microbiol Infect 2004;10:1006-8.

26. Nakayama J, Kariyama R, Kumon H. Description of a 23.9-kilobase chromosomal deletion containing a region encoding fsr genes which mainly determines the gelatinasenegative phenotype of clinical isolates of Enterococcus faecalis in urine. Appl Environ Microbiol 2002;68:3152-5.

27. Sedgley C, Lennan S, Clewell D. Prevalence, phenotype and genotype of oral enterococci. Oral Microbiol Immunol 2004;19:95-101.

28. Roberts J, Singh K, Okhuysen P, Murray B. Molecular epidemiology of the fsr locus and of gelatinase production among different subsets of Enterococcus faecalis isolates. J Clinical Microbiol 2004;42:2317-20.

29. Heidari H, Emaneini M, Dabiri H, Jabalameli F. Virulence factors, antimicrobial resistance pattern and molecular analysis of Enterococcal strains isolated from burn patients. Microb Pathog 2016;90:93-7.

30. Shankar N, Lockatell C, Baghdayan A, Drachenberg C, Gilmore M, Johnson D. Role of Enterococcus faecalis surface protein esp in the pathogenesis of ascending urinary tract infection. Infect Immun 2001;69:4366-72.

31. Tendolkar P, Baghdayan A, Gilmore M, Shankar N. Enterococcal surface protein, esp, enhances biofilm formation by Enterococcus faecalis. Infect Immun 2004;72:6032-9. 
32. Zoletti G, Siqueira J, Santos K. Identification of Enterococcus faecalis in root-filled teeth with or without periradicular lesions by culture-dependent and independent approaches. J Endod 2006;32:722-6.

33. Bortolaia V, Espinosa-Gongora C, Guardabassi L. Human health risks associated with antimicrobial-resistant enterococci and Staphylococcus aureus on poultry meat. Clin Microbiol Infect 2016;22:130-40.

34. Christoffersen T, Jensen H, Kleiveland C, Dørum G, Jacobsen M, Lea T. In vitro comparison of commensal, probiotic and pathogenic strains of Enterococcus faecalis. $\mathrm{Br} \mathrm{J}$ Nutr 2012;108:2043-53.

35. Creti R, Imperi M, Bertuccini L, Fabretti F, Orefici G, Di Rosa R, et al. Survey for virulence determinants among Enterococcus faecalis isolated from different sources. J Med Microbiol 2004;53:13-20.

36. Eaton T, Gasson M. Molecular Screening of Enterococcus Virulence Determinants and Potential for Genetic Exchange between Food and Medical Isolates. Appl Environ Microbiol 2001;67:1628-35.

37. Joghataei M, Yavarmanesh M, Dovom MRE. Safety evaluation and antibacterial activity of Enterococci isolated from lighvan cheese. J Food Safety 2017;37:e12289.

38. Aspri M, Bozoudi D, Tsaltas D, Hill C, Papademas P. Raw donkey milk as a source of Enterococcus diversity: Assessment of their technological properties and safety characteristics. Food Control 2017;73:81-90.

39. Biscola V, Choiset Y, Rabesona H, Chobert JM, Haertlé T, Franco B. Brazilian artisanal ripened cheeses as sources of proteolytic lactic acid bacteria capable of reducing cow milk allergy. Jappl Microbiol 2018;125:564-74. 